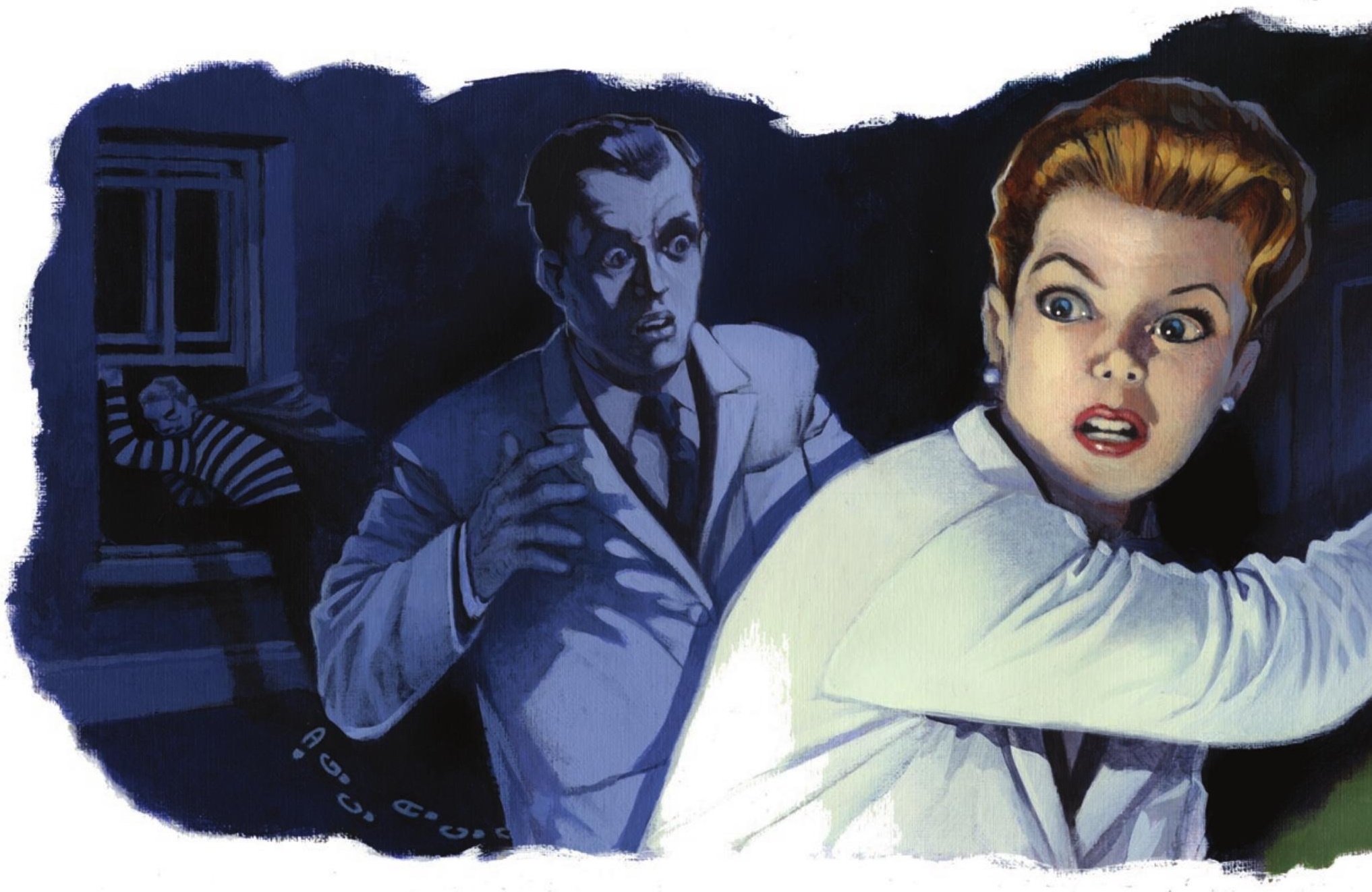

\title{
The case of the missing heritability
}

\section{「失われた遺伝率」のミステリー}

Nature Vol.456 (18-21) / 6 November 2008

ヒトゲノム時代の扉が開かれたとき、ありふれた形質や疾患の遺伝的要因は簡単に見つかるだろうと期待された。ところが、光んな ものはほとんどどこにも見当たらなかった。こうした行方不明の「戦利品」が隠されてい父うな 6 つの場所に、Brendan Maher が光 を当てる。

自分の子どもが成人してどのくらいの身長 になるかを予測したいなら、鏡に映る自 分の背丈と、配偶者の背丈を見ればほぼ 確実にわかるだろう。およそ1 世紀前の 研究で、身長は80 90\% の確率で遺伝 すると見積もられている。だとすると、集 団の身長の高いほうの $5 \%$ と低いほうの $5 \%$ の差が 29 センチメートルの場合、そ
のうち 27 センチメートルは遺伝的要因に よるもの、つまりほとんどは遺伝で説明が つくと考えられる ${ }^{1}$ 。

2008 年に 3 つの研究グループ ${ }^{2-4}$ が、 身長差に関連する遺伝的変異について大 規模ヒ卜集団（最大規模の調査 ${ }^{4}$ では対象 者が 3 万人以上）のゲノムを詳しく調べた。 すると、40 個を超える遺伝子が見つかった。
ところが 1 つ問題があった。遺伝的変 異の影響はわずかしかなかったのだ。そ れらの変異を総合しても、身長の遺伝 率の $5 \%$ しか説明がつかなかったのであ る。前述の計算によれば、相当するのは わずか 6 センチメートルにすぎない。こ れらのゲノムワイド相関解析 (GWAS) で 何十個もの変異が見つかったにもかかわ 
そして、目標はある程度達成され、さまざ まな形質やありふれた疾患に関与する遺 伝的変異を 400 個以上見つけ出すことが できた。しかし、数十個の遺伝子が 1 つ の形質に関連づけられた場合であっても、 個々の遺伝子の効果も全体の複合効果も がっかりするほど小さく、これまでの遺伝 率の推定值を十分説明できるとはとても いえない。「これは、ありふれた疾患の遺 伝に関する、現時点での重要な課題です」 と、米国立ヒトゲノム研究所 (NHGRI； メリーランド州ベセスダ）の前所長である Francis Collins はいう。こうした予想外 の結果に、「研究者らは全員頭をかきつつ 『あれ?』というよりほかありませんでし た」と彼は語った。

この「失われた遺伝率 (missing heritability)」という失敗があったにも かかわらず、遺伝学者たちはもっと見つ けられると楽観的な姿勢を崩していない。 「今は時期尚早なのです。しかし、1〜2 年で実現可能となり、相当な数の形質に ついて遺伝率をうまく説明できるようにな るのではないでしょうか」とHirschhorn はいう。では、遺伝率の不足分はどこに らず、こうした変異からの「予測は、両 親の身長に基づく予測にほとんど及ばな かったのです」と、これらの研究の $1 \supset^{3}$ を指揮したブロード研究所（米国、マ サチューセッツ州ケンブリッジ）の Joel Hirschhorn はいう。

身長は、関連遺伝子の行方がわからな い唯一の形質というわけでもないし、最 も重要な形質というわけでもない。一卵 性双生児と二卵性双生児の類似性に着目 した研究では、自閉症の遺伝率は $90 \%$ を超え 5 、統合失調症では $80 \%$ を超え る ${ }^{6}$ と見積もられている。また、遺伝は肥 満や糖尿病、心疾患などの疾患に大きく かかわっている。ゲノムワイド相関解析は この 5 年間で最も華々しく取り上げられ た技術の 1 つであり、関与する遺伝子を 多数見つけ出せるものと期待された（21 ページコラム「見返りはどこに?」を参照)。 まぎれていると考えられるのだろうか。

\section{すぐ目の前に}

見つからない遺伝子もあったが、それは ゲノムワイド相関解析の限界ということで 説明できた。この解析により、DNAの 1 文字（1 塩基）の变異が多数見つかっ た。これは一塩基多型 (SNP ; スニップ) とよばれ、大勢の人で 1 つの疾患やその 他の形質に関連して共通にみられる变異 である。しかし、1 個のSNP は、遺伝物 質のかなり大きいブロック 1 個を代表する 「指標」である。すると、例えば、もし 2 人のヒトが身長に関連するゲノム領域の 1 つの重要な位置にこうした変異の 1 つを 共通してもっていたなら、実際にはそのう ちの 1 人は身長に大きな影響を及ぼす比 較的まれな变異を別の部位にもっている 場合でも、2人ともその領域に身長に関
連する遺伝子の同一バージョンをもってい るものとして記録されてしまう可能性があ る。NHGRI の集団ゲノミクス局の局長を 務めるTeri Manolioによれば、相関解 析によって、身長差の原因となる変異を特 定できるかもしれないが、何千人もの調 査対象者を平均化することで、その効果 がかなり薄まってしまうようにみえるとい う。そして、「実際、薄まるでしょう」と 彼女は話している。

この種の「失われた遺伝率」を見つ け出すことは、概念的にはたやすい。既 に見つかっている遺伝子をもっと詳しく 調べればよいからだ。「既に見つかって いる遺伝子座にある遺伝的変異を非常 に緻密に調べるだけで、失われた遺伝 率を増加させることができるでしょう」と Hirschhorn は話す。疾患とのさらなる 関連性を明らかにしようとするなら、千人 単位のヒ卜集団を対象に、候補とされる遺 伝子やその周囲領域の塩基配列の解読が 必要になるだろう。

テキサス大学サウスウェスタン医療 センター（米国、ダラス）の Helen Hobbs とJonathan Cohen は、遺伝子 ANGPTL4 にある変異すべてをとらえよう と、実際にこうした解析作業を行った。彼 らは既に、この遺伝子がコレステロール值 とトリグリセリド（中性脂肪）濃度に関連 していることを明らかにしていた。ダラス 心臓研究 (Dallas Heart Study) の対 象者およそ3500 人でこの遺伝子の塩基 配列解読を行い、それまで知られていな かったいくつかの変異がこれらの脂質の血 中值に劇的な影響を及ぼしていることを見 つけた 7 。英国のオックスフォード糖尿病 内分泌代謝センターの Mark McCarthy は、こうした調査によって「失われた遺伝 率」の多くが明らかになるのではないかと 話すが、こうした調査に意欲をもつ人々は あまり多くないのだともいっている。ただ し、塩基配列解読のコストが下がっている ので、この状況は変化するのではないかと 思われる。 


\section{見えないところに}

ゲノムワイド相関解析では手がかりのヒン トさえつかめなかったほかの変異は、見 つけるのがもっとむずかしいことが明らか になるだろう。過去には、囊胞性繊維症 などの遺伝疾患に関する従来型の遺伝学 研究から、浸透度の高い変異遺伝子がま れに同定されている。浸透度とは、遺伝 子が実際に表現型として現れる割合のこと で、これが高いということは、その遺伝子 をもつほぼすべての人に効果が現れるこ とを意味する。しかし、進化はこうした浸 透度の高い変異を概して抑制するものな ので、そうした変異は大半のありふれた 疾患の基盤にはなっていないらしいことが じきに明らかになった。

ゲノムワイド相関解析を推し進めたの は、ある仮説だった。それは、運の悪い 1 人の人間にありふれた低浸透度の変異 が十分な数だけ現れた場合、そうした変 異によってありふれた疾患が引き起こされ
るのだとする仮説である。今やこの仮説 は疑問視されるようになりつつある。「あ りふれた変異のスクリーニングがかつて期 待されたほどには形あるものを生み出し ていないことに、大勢の人が気づきつつ あるのです」と、デューク大学（米国、ノー スカロライナ州ダラム）で遺伝学教授を務 める David Goldstein はいう。

しかし、非常に目立つ変異と、ゲノムワ イド相関解析の「大きい網」にかかるくら いのありふれた変異との中間には、浸透 度は中程度だがゲノムワイド相関解析の 網にはかからないくらい希少な変異が存 在していると考えられる。また、それらよ りも頻度が高く、ゲノムワイド相関解析で は疾患との相関を統計的に関連づけるこ とができないくらい浸透度の低い变異が、 多数存在している可能性もある。

こうした非常に低浸透度の変異はいく つかの問題を突きつけていると、プリン ストン大学（米国、ニュージャージー州）

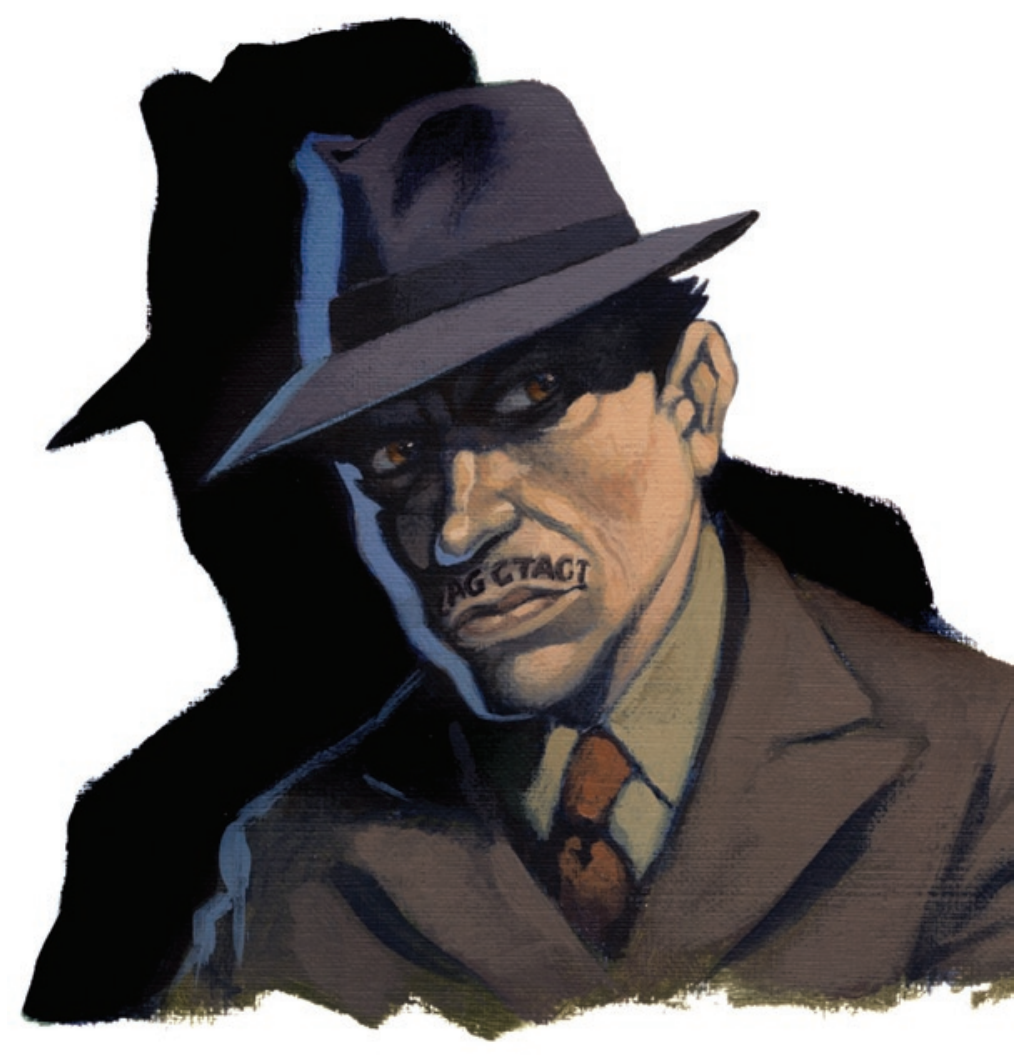

で生態学と進化生物学の教授を務める Leonid Kruglyak はいう。「それぞれの 変異は低浸透度であっても、全体として 80\% とか 90\% の遺伝性を示す何千という 変異について言及することになるのです」。 極端にいってしまうと、例えばゲノム内の 事実上すべての遺伝子に、身長に影響す る変異が 1 つあかもしれないということ になる。「そんなモデルについて考えたく はないでしょう」とKruglyak はいう。

低頻度で中くらいの浸透度か、あるい は高頻度で弱い浸透度の変異が「容疑 者」だとすると、既存の相関解析で調査 対象者の数を増やせば、これまで見逃 されてきた遺伝的相関を見つけられるか もしれない。クィーンズランド医学研究所 (オーストラリア、ブリスベン) の Peter Visscherによれば、およそ10 万人を対 象とする身長調査のメ夕解析が現在進行 中だという。関連づけの厳密性を緩くす ればもっと多くの变異が拾い上げられるか もしれないが、「当たり」変異の信頼度は 低下してしまうだろう。

SNP の利用をどこかの時点でやめて、 全ゲノムの塩基配列解読に着手することは 理にかなっているかもしれない。NHGRI では、世界中の少なくとも 1000 人の ゲノム塩基配列の解読をめざす「1000 人ゲノムプロジェクト」が始動している。 Collins の意見によれば、この計画は隠 れた遺伝率を見つけ出すのに大いに貢献 できそうであり、塩基配列解読の費用が 安くなっているので、もっと大勢のゲノム 解読が可能になるかもしれないと示唆し ている。

総力を挙げた膨大な量の塩基配列解 読を誰もが支持しているわけではない。 Goldstein は、こうしたプロジェクトの「エ ンジンをかけ続ける」には、疾患の兆候 を強く示す人たちのゲノム塩基配列を解読 するなど、もっと合理的な方法を考え出す べきだと、警鐘を鳴らしている。「ゲノム ワイド相関解析で行ったのと同じ塩基配列 解読手法で再び解析を行うことには、賛 


\section{見返りはどこに？}

「失われた遺伝率」の謎を解 くことは、学術的な満足を得 ることだけにとどまらない。ゲ ノムワイド相関解析は、あり ふれた疾患に関連する変異を 見つけ出して有意義な医療情 報を提供してくれるものと期待 され、ヒトゲノム解析への 30 億ドル（2700 億円； 1 ドル $=90$ 円で換算）やヒト変異 マッピング研究への数百万ド ルといった資金投入も当然だ と考えられた。「これほどの大 金が費やされてきたのは、遺 伝率の大半がこれではっきり するだろうと考えられたからで す」とケース・ウエスタン・リ ザーブ大学の遺伝学者である Joseph Nadeau はいう。

誰かの遺伝子からその身長 を予測するということは、ちょっ とした手品程度のことなのか もしれない。しかしこれによっ て、生命をつづる「言語」、す
なわち遺伝情報が支配された ことになり、医療の多くの分 野にまでその影響が及ぶと考 えられる。しかし、一部の予 期せ女驚きの発見は別として、 見つかった変異の多くはヒト の形質にささやかな影響しか 及ぼさない。その一例が、加 齢黄斑変性症という眼の疾患 に結びつけられる免疫系遺伝 子の変異である。現在のとこ ろ、遺伝解析によって家系解 析よりもはっきりとした、将来 かかりうる疾患に関する「答 え」を得られた例はまれにし かない。そして治療への道も 平坦ではないと、デューク大学 の David Goldstein は語る。 「遺伝解析を用いて、大半の ありふれた疾患に関する個人 用リスクプロファイルを作成す る話や、新しい薬剤標的が大 量に見つかるという話などが 話題になっています。それは
現時点では明らかに甘い考え だと私は思っています」。

米国立ヒトゲノム研究所の前 所長であるFrancis Collins は、疾患予測は依然として無 理なままだという見方に賛成し ているが、治療的介入につい てはまだ楽観的である。ゲノム ワイド相関解析で見つかった遺 伝的変異の大半は「比較的地 味なリスクに関与しているが、 これらの遺伝子が重要でない とは決していえない。こうした 遺伝子には、びっくりするよう な治療のきっかけが潜んでいま す」と彼は話す。

クィーンズランド医学研究 所の遺伝学者であるPeter Visscherも、同じ意見である。 「ゲノムワイド相関解析を非難 して、あらゆることが期待され たのに何ももたらさなかったと 責めることはたやすいでしょう。 しかし、疾患に関与する遺伝
子や経路を突き止めるという 意味では、非常に成功を収め ました。この分野を大いに前 進させたと私は思っています」。

結局のところ、ゲノムワイド 相関解析で探し出された変異 が臨床でどんな価值をもつか は、疾患によってまちまちかも しれない。この研究分野はい まだに、臨床に応用して疾患 予測や疾患の個人プロファイ リング、個人に適した治療に 利用したり、薬剤標的の特定 などに活用したりすることにこ だわりすぎている。カリフォル ニア大学サンフランシスコ校 の Robert Nussbaum は単 刀直入にこういっている。「ヒ 卜遺伝学は、得られた成果を、 すぐに具体的なものに転化す ベきだとみなされるのが常で す。しかし、現在行われてい るのは基礎研究なのです」。

B.M.
成ではありません」と彼はいう。「それは 規模も大きく費用もかかる解析作業であ り、誰を再び配列解読するかをもうちょっ と厳しく検討したほうがいいと思います」。

\section{構造の中に}

現在、一部の研究者はコピー数変 異 (CNV) に的を絞って研究している。 CNVとは、数十から数百個の塩基対にあ たるDNA 鎖が、個人によって欠失してい たり重複していたりする変異である。この 種の変異は、統合失調症や自閉症などの 疾患で、失われた遺伝率の説明に用いら れ始めているようである。これまでゲノム ワイド相関解析では、これらの疾患で失わ れている遺伝率についてほとんど何も見
つかっていない、最近の 2 つの研究では、 健常者と統合失調症患者の数百の CNV を調べ、統合失調症といくつかの CNVの 間に強い相関を見いだした ${ }^{8,9}$ 。これらの CNVは通常、新たに生じたもので、それ らをもつ各個人の家系には同じ変異をも つ者がいない。

こうした構造上の変異で、個人間の遺 伝的なばらつきの多くを説明できる可能 性があり、また、ゲノムワイド相関解析で は拾えない中浸透度の希少な「目につか ない」変異の一部について説明できるか もしれない。多くのCNVはSNP の順序 を変化させないので、検出されずにいる。 重複した領域の配列解読もむずかしい己 とがある。
CNVを検出するための標準的な技術の 1 つは、アレイ比較ゲノムハイブリダイゼー ションである。さまざまな人から採取した 遺伝物質がマイクロアレイ上でどのように ハイブリッド形成するかを調べる手法であ る。アレイ上の特定のスポットが多少の DNA を検出した場合、そ己には CNVが あることを示していると考えられる。この 手法やほかのいくつかの手法については、 ウエルカムトラスト・サンガー研究所（英 国、ケンブリッジ）が運営しているコン ソーシアム、「コピー数変異プロジェクト（ Copy Number Variation Project)」 によって現在検証されているところであ る。同コンソーシアムは、疾患との関連 づけができるCNVの特性解析を、可能 
なかぎり数多く行うことをめざしている。 McCarthyの話では、遺伝率における CNVの隠れた役割は、「6か月から 1 年 で明らかになるはずです」という。しかし Goldstein は、50 塩基対からわずか 2 塩基対までの反復のような小さい CNVの 多くは、現在の技術では見逃されてしまう だろうと主張する。「我々が確認できるで あろう CNV はすべて、検出の可能な大規 模な CNVであり、そうしたものは失われ た遺伝率の多くを説明できないことが明ら かです」。

\section{裏のネットワークに}

大半の遺伝子は密接な関係にあるほかの 遺伝子と一緒に働くので、遺伝率に対す る 1 個の遺伝子の影響は、共同で働くほ かの遺伝子の影響がわからないと検出で きないと考えられる。これはエピスタシス の一例である。エピスタシスとは、1個の 遺伝子が別の遺伝子の影響を覆い隠して しまったり、数個の遺伝子が同時に働い て影響し合ったりすることである。例えば 2 個の遺伝子があって、それぞれによって 身長が 1 センチメートル加算されるが、2 個そろうと 5 センチメートル加算されると いう具合である。ゲノムワイド相関解析は エピスタシスにあまりよく対応しておらず、 こうした相互作用を見つける解析には通 常、前もって、相互作用の相手に関して 十分予測しておくことが必要である。

ケース・ウエスタン・リザーブ大学（米 国、オハイオ州クリーブランド）の遺伝学 者、Joseph Nadeauによれば、単純な 機構の単一遺伝子疾患であっても、「修飾 遺伝子」が働いているのだという。「これ が単純な型のエピスタシスです」と彼はい う。例えば囊胞性繊維症はCFTR という 1 個の遺伝子の変異によって起こるが、そ の症状や重症度には大きな差がある。こ のばらつきの原因の 1 つが修飾遺伝子な のではないかという疑惑は、以前からも たれていた。

しかし、何年も研究を重ねているにも
かかわらず、研究者らはこうした遺伝子の 検出に今もまだ四苦八苦している。「エピ スタシスの影響の正確なモデル化がまだ なされていないのです」と、ペンシルベニ ア大学（米国、フィラデルフィア）の集団 遺伝学者Sarah Tishkoff は話す。

当然のことながら、遺伝というものは、 1 個の遺伝子に 1 つ表現型が対応す るか、もしくは数個の遺伝子に 1 つの表 現型が対応するというものではなく、もっ と複雑である。しかし、そうしたもっと複 雑なありさまがどの程度把握されるよう になってきたかというと、現状はかなり 悲惨である。近年の古典的な研究 ${ }^{10}$ で Kruglyakたちは、酵母の遺伝子の大半 ではいくつかの変異によって発現が制御さ れており、そうした変異は多くの場合 6 個 以上であることを見つけた。遺伝率の不 足部分をすべて埋めるためには、遺伝子 と調節配列からなるネットワーク全体や、 そうした遺伝子などが共同で 1 つの表現 型を生じる仕組みについて、もっとすぐれ たさまざまなモデルが必要なのかもしれ ない。このプロセスはよりシステム生物学

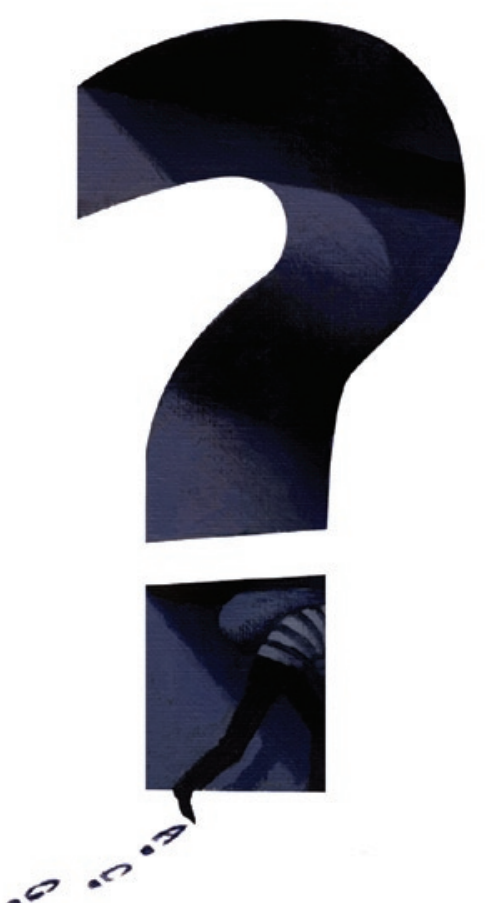

に近づくと考えられ、研究者たちは既に、 ヒトやその他の生物へシステム生物学の 手法を適用している (Nature2008 年 11 月 6 日号 26 ページ参照)。「我々が現在、 こうした研究から学びつつあることは、複 雑なモデルをより単純化したものではな く、複雑なモデルをより複雑化したものに ついて考える必要があるということです」 とKruglyak はいう。

\section{あの世のご先祖様に}

そもそも最初の段階で遺伝率の見積もり が間違っていたら、どうなるのだろうか。 身長の遺伝率はもともと、両親の平均身 長と子どもたちの成人時の身長を比較し て算出されたものだ。両親の平均身長が 高くなれば子どもの平均身長も高くなり、 遺伝率は80 90\%と計算された。

環境要因、なかでも重要な成長段階で 栄養素や有害物質などの要因により、集 団の平均身長に有意な影響が出てくるこ とがある。しかし解析にあたって、例えば 一卵性双生児が一緒に暮らして成長した 場合と離れて暮らして成長した場合を比較 することで、遺伝率の算定值における環 境の影響を調整できる。大多数の研究者 は、身長の遺伝率の算定値が妥当である と確信している。「本当は身長の遺伝率は $10 \%$ あり、失われた遺伝率と思われて いたものの要因が環境だという専門家が いるとは思われません。環境要因が失わ れた遺伝率をうまく説明できると思えませ んからね」とKruglyak はいう。

しかし、遺伝率研究で環境要因につい てどのくらい的確に説明してきたかについ ては、根強い疑念がある。サウサンプトン 大学（英国）のDavid Barkerによれば、 子宮内での有害な経験が生涯にわたる健 康格差につながる可能性があるが、それ にもかかわらず、この種の研究には、胎 児と母胎の子宮の共有という環境要因は なかなか織り込まれないのだという。「遺 伝率の算定值は基本的に家族に集約する ものであり、環境要因も家族に集約する 
問題なのです」とManolioはいう。

塩基配列の変化によらずに世代間で継 承されるような遺伝子発現の変化を、エピ ジェネティクスといい、この現象により問 題はさらに混乱している。例えば、マウス にある特定の餌を与えると、生まれてくる 仔マウスの毛色が変わり、そればかりか 孫の代のマウスまで毛色が変わる ${ }^{11}$ 。こ の場合、1個の毛色遺伝子の発現が、メ チル化とよばれる DNA 修飾作用によって 制御されている。しかし、次世代までメチ ル化パターンが「記憶される」仕組みは、 それだけでは完全に明確にはならない。 祖母の経験した環境がその後の世代にま で影響を及ぼすのではないかとする説は、 現在議論をよんでいる。従来の「遺伝子 による遺伝率」の算定值には、そうした 環境の影響が含まれていると考えられる。

「この問題はすべてをややこしくします」 とNadeauはいう。「曾祖父や曾祖母が 若いころや子どもを授かったときに、どん な環境にさらされていたかなど、いったい どうやったら知ることができるというので しょう」。そこで役立ちそうなのが、モデ ル生物である。Nadeauの研究チームは、 ヒトで高度な遺伝性のがんに似たマウス の精巣の胚細胞腫瘍を調べた。そして、 1 個の弱いがん促進遺伝子である Dnd $7^{\text {Ter }}$ の作用がほかのいくつかの変異型遺伝子 によって大きく増強されることや、増強さ れた影響はたとえそれらの原因遺伝子が なくても受け継がれることを見つけた ${ }^{12} 。$ 「おそらくその存在は、何らかのエピジェ ネティックな方式で受け継がれるのでしょ う」とNadeauはいう。ただし、エピジェ ネティックな遺伝がいったいどんな仕組み で働くのかはまだ論争の的になっている。 一生の間の遺伝子発現を方向づけるメチ ル化などの刻印は、新しい肧ではすべて いったんリセットされてやり直されると考 えられている。Nadeauによれば、彼の 観察結果に対して考えられる説明の 1 つ は、RNAが精子または卵を介してDNA と一緒に受け継がれることだという。

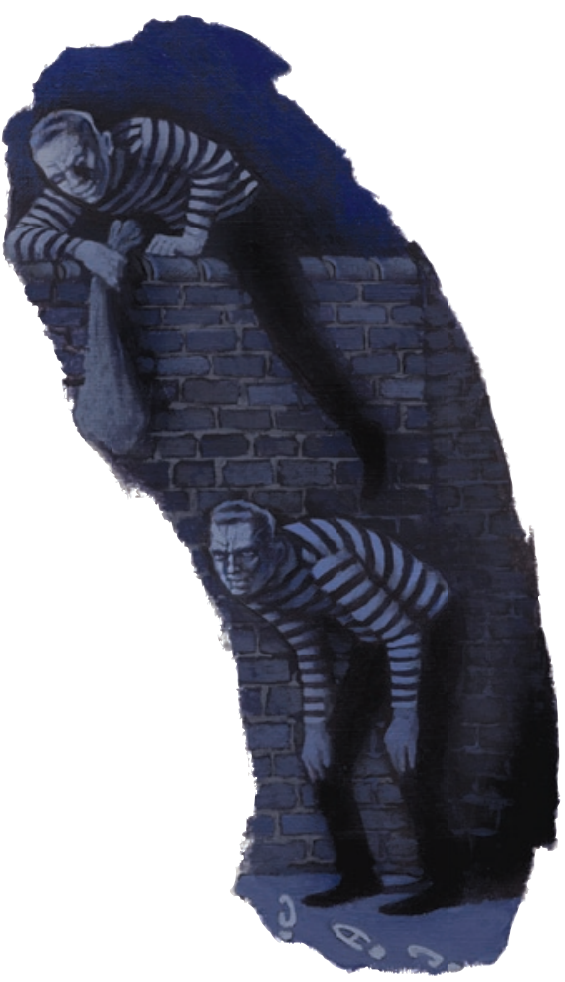

ろうか。本当は、これらは異なる疾患な のではないだろうか。

研究者たちは、たとえあったにしてもご く少数の素因遺伝子を共有するヒ卜集団 で共通の素因遺伝子を探しているところ であり、ゲノムワイド相関解析が実際には かなりむずかしいことだと判りつつあるだ ろう。それでも、もっと踏み込んで遺伝的 特性を解明しないかぎり、疾患をきちん と分類できるかどうかわからない。「まれ な変異で起こるありふれた疾患なのかも しれません。そして、そうした変異を見つ けるのは一段とむずかしいので、人々は 何となく恐怖心を抱いてしまうのです」と Tishkoff はいう。

現在議論さえされていない行方不明の 遺伝率には、もっと恐ろしくもっと手に負 えない原因が潜んでいるのかもしれない。 「我々が根本からまるで理解していないよ うな何かが存在する可能性があります。そ れは我々が今考えているものとあまりにか け離れており、想像もつかないようなもの

Collinsは、ヒトの「失われた遺伝率」 にエピジェネティクスが大きな役割を果た しているとは思っておらず、「1つか 2 つ の例を除けば、この説が正しいとは考え られない」と話す。Nadeauはこれに反 発しており、「ほかのすべての生物で機能 している機構が、ヒトだけが例外として機 能していないとは考えにくいです」と述べ ている。

\section{病名診断にまぎれて}

研究者が遺伝率を追求しようとするとき、 どうしても消えない懸念がある。それは、 ありふれた疾患といわれるものが実際には 「ありふれて」いないのではないかとい う疑いだ。医学では、さまざまな症状の 複雑な集合体を何とかひとくくりにして、 1 つの病名をつけようとする。しかし、単 一の疾患に数千ものまれな遺伝的変異が 関与していて、その遺伝的な基盤が個人 ごとに根本的に異なっている可能性があ る場合、「ありふれている」といえるのだ
なのです」とKruglyak はいう。

Kruglyak にとっても、ほかの多くの基 礎研究者にとっても、この「失われた遺 伝率」というミステリーは依然として謎に 満ちている。「遺伝現象は、子どもは親に 似るという明白で目に見えるものです。小 学校の理科の話題であるにもかかわらず、 いったいどういう仕組みになっているのか はほとんどわかっていないのです」。彼は こう語っている。

Brendan Maher は Nature 特集記事のエディター。

Visscher, P. M. Nature Genet. 40, 489-490 (2008)

2. Weedon, M. N. et al. Nature Genet. 40, 575-583 (2008).

3. Lettre, G. et al. Nature Genet. 40,584-591 (2008).

4. Gudbjartsson, D. F. et al. Nature Genet. 40, 609-615 (2008)

5. Sullivan, P. F. PLoS Med. 2, e212 (2005).

6. Freitag, C. M. Mol. Psychiatr. 12, 2-22 (2007)

7. Romeo, S. et al. Nature Genet. 39, 513-516 (2007).

8. Stefansson, H. et al. Nature 455, 232-237 (2008)

9. The International Schizophrenia Consortium Nature 455 237-241(2008).

10. Brem, R. B., Yvert, G., Clinton, R. \& Kruglyak, L. Science 296, 752-755 (2002).

11. Waterland, R. A. \& Jirtle, R. L. Mol. Cell. Biol. 23, 5293-5300 (2003)

12. Lam, M. Y., Heaney, J. D., Youngren, K. K., Kawasoe, J. H. \& Nadeau, J. H. Hum. Mol. Genet. 16, 2233-2240 (2007). 